\title{
KARBON MONOKSIDA (CO) PADA IBU HAMIL (PEROKOK PASIF) TERHADAP KEJADIAN BAYI BERAT LAHIR RENDAH (BBLR) DI WILAYAH KABUPATEN KUNINGAN
}

\author{
Fitri Kurnia Rahim, Andy Muharry \\ Sekolah Tinggi Ilmu Kesehatan Kuningan Garawangi \\ fikura.zone@gmail.com
}

\begin{abstract}
Abstrak
Bayi berat lahir rendah (BBLR) masih menjadi permasalahan di negara berkembang. Berdasarkan laporan riset kesehatan dasar tahun 2013 menunjukan bahwa proporsi BBLR di Indonesia yaitu $10.2 \%$. Paparan asap rokok dapat menjadi faktor resiko terjadinya BBLR. Berdasarkan Riskesdas (2013) sebesar 85\% rumah tangga Indonesia terpapar asap rokok. Tujuan penelitian ini adalah untuk mengetahui hubungan kadar karbon monoksida (CO) hamil perokok pasif dengan kejadian BBLR.

Jenis penelitian menggunakan desain kasus kontrol. Populasi penelitian adalah ibu hamil yang melahirkan pada periode waktu Januari 2017 sampai dengan Maret 2018 di wilayah Puskesmas Manggari Kabupaten Kuningan. Adapun besar sampel dalam penelitian yaitu total sampling sebanyak 27 orang dengan ratio 1:1. Sehingga jumlah sampel sebanyak 54 orang. Selain itu penelitian ini didukung dengan data kualitatif menggunakan kombinasi (mix method) model concurrent-embedded. Instrumen penelitian berupa kuesioner dan alat pengukur karbon monoksida (CO) yaitu Micro ${ }^{+}$тм Smokerlyzer. Analisis data dilakukan melalui analisis univariat, bivariat (uji chi-squre) dan analisis data kualitatif.

Hasil penelitian menunjukan 54,2 \% ibu yang memiliki kadar CO kategori berbahaya mengalami kejadian BBLR. Sebanyak $46.7 \%$ ibu yang memiliki kadar CO kategori normal mengalami kejadian BBLN. Perbedaan proporsi berdasarkan kategori kadar CO pada ibu antara kelompok kasus (BBLR) dan kontrol (BBLN) tidak berbeda secara signifikan (p;0,584; OR:1,4; 95\%CI:0,460-3,964).
\end{abstract}

Kata Kunci: Karbon monoksida, perokok pasif, ibu hamil, bayi berat lahir rendah (BBLR)

\section{Pendahuluan}

Kejadian berat bayi lahir rendah (BBLR) banyak terjadi di Negara berkembang dibandingkan Negara maju (Wardlaw, 2004). Berdasarkan laporan riset kesehatan dasar (Riskesdas) tahun 2013 menunjukan bahwa prevalensikejadian BBLR di Indonesia yaitu $10.2 \%$. Prevalensi kejadian BBLR lebih tinggi di wilayah pedesaan ddibandingan di perkotaan, masing-masing $11.2 \%$ dan 9.4 $\%$. Persentase BBLR tertinggi terdapat di provinsi Sulawesi Tengah (16,9\%) dan terendah di Sumatera Utara (7,2\%). Menurut kelompok umur, persentase BBLR tidak menunjukkan pola kecenderungan yang jelas. Persentase BBLR pada bayi perempuan $(11,2 \%)$ lebih tinggi daripada laki-laki (9,2\%).

Adapun prevalensi kejadian BBLR di Jawa Barat pada tahun 2010 sampai 2013 tidak mengalami penurunan yang signifikan. Prevalensi kejadian BBLR di Jawa Barat pada tahun 2013 hampir sama dengan rata-rata prevalensi nasional (10.1 
JURNAL ILMU KESEHATAN BHAKTI HUSADA: HEALTH SCIENCES JOURNAL, VOL. 10 NO. 01, JUNI 2019

DOI: https://doi.org/10.34305/jikbh.v10i1.86

\%). Berdasarkan hasil laporan pemerintah Provinsi Jawa Barat, Kabupaten Kuningan mengalami kenaikan angka kejadian BBLR yaitu dari sebanyak 1101 kasus BBLR pada tahun 2014 hingga 1185 kasus pada tahun 2015 dari total kelahiran hidup. Kabupaten Kuningan merupakan Kabupaten yang menempati urutan keenam tertinggi kasus BBLR di wilayah Jawa Barat.

Ada banyak faktor risiko yang diketahui mempengaruhi BBLR, diantaranya adalah sosio-ekonomi, risiko medis sebelum atau selama masa gestasi dan gaya hidup ibu(De Bernabé et al., 2004, Mahayana and Chundrayetti, 2015), jarak kehamilan, paritas, kadar hemoglobin (Marlenywati et al., 2017). Selain itu, faktor risiko terjadinya BBLRberkaitan erat dengan permasalahankesehatan ibu selama masa kehamilan danpersalinan, yang mana salah satunya adalahadanya paparan asap rokok pada ibu selamakehamilan.Paparan dari asap rokok dapatmempengaruhi perkembangan janin didalam kandungan karena nikotin dan karbonmonoksida di dalam rokok dapatmenghambat distribusi nutrisi dari ibu kejanin. Hal ini akan berdampak padaperkembangan janin, kondisi dan beratbadan lahir bayi pada waktu persalinan. Beberapa penelitian mengemukakan terdapat hubungan signifikan antara paparan asap rokok pada ibu hamil terhadap kejadian BBLR (Lestari and Mangku, 2015, Ramadhan, 2012, Leonardi-Bee et al., 2008, Salmasi et al., 2010, Martin and Bracken, 1986). Ibu hamil yang terpapar asap rokok anggota keluarga pada rumah tangga sembilan kali beresiko mengalami kejadian berat bayi lahir rendah (Lestari and Mangku, 2015).

Berdasarkan Riskesdas, (2013) sebesar $85 \%$ rumah tangga Indonesia terpapar asap rokok, dapat diesestimasikan bahwa delapan perokok meninggal karena perokokaktif, satu perokok pasif meninggal karenaterpapar asap rokok orang lain. Berdasarkan perhitungan, maka sedikitnya 25.000 kematian di Indonesia terjadi dikarenakan asap rokok orang lain (Infodatin, 2015:3). Hasil studi pendahuluan di Kuningan menunjukan masih banyaknya perokok aktif yang merokok ditempat umum dan di dalam rumah. Telah diketahui sebanyak $65 \%$ perokok dalam rumah tangga yang merokok dalam rumah. Selain itu, hasil studi melaporkan bahwa kadar CO pada sebagian perokok aktif dan pasif tidak jauh berbeda, masing-masing rata-ratanya $31.2 \mathrm{ppm}$ dan $15.6 \mathrm{ppm}$. Nilai tersebut mengindikasikan kadar $\mathrm{CO}$ perokok aktif dan pasif di wilayah tersebut terdapat dalam zona berbahaya.Rokok mengandung 4000 bahankimiadan 200 diantaranyaberacun, sepertinikotin, gas karbonmonoksida (CO) dan tar. Hasil studi melaporkan bahwa paparan ambient $\mathrm{CO}$ pada ibu hamil dapat berpengaruh terhadap ibu hamil sehingga dapat berdampak pada kejadian BBLR (Ritz and $\mathrm{Yu}, 1999$ ). Fenomena tersebut sangat membahayakankesehatan anggota keluarga, terutama bagiibu hamil yang berdampak padaperkembangan janin dan kondisi beratbadan bayi pada saat lahir. Penelitian ini dilakukan untuk mengetahui hubungan kadar karbon moksida (CO) pada ibu hamil sebagai perokok pasif terhadap kejadian berat bayi lahir rendah (BBLR).

\section{Metode}

Penelitian ini merupakan studi observasional analitik dengan pendekatan case control yang dilakukan di wilayah kerja Puskesmas Manggari Kab. Kuningan. Kegiatan penelitian ini dilaksanakan pada April-Mei 2018. Populasi penelitian adalah ibu hamil perokok pasif. Adapun sampel penelitian terdiri dari 27 kasus (berat bayi lahir rendah) dan 27 kontrol (berat bayi lahir normal) yang memenuhi kriteria penerimaan. Kasus adalah ibu yang pernah hamil yang melahirkan pada periode 1 Januari 2017 - 30 Maret 2018, dengan kondisi berat bayi lahir rendah dan tidak melahirkan kembar. Adapun kontrol adalah ibu yang pernah hamil dan melahirkan pada periode 1 Januari 2017 - 30 Maret 2018, dengan kondisi berat bayi lahir normal dan tidak melahirkan kembar. Responden 
JURNAL ILMU KESEHATAN BHAKTI HUSADA: HEALTH SCIENCES

JOURNAL, VOL. 10 NO. 01, JUNI 2019

DOI: https://doi.org/10.34305/jikbh.v10i1.86

dalam penelitian ini adalah ibu balita yang terpilih menjadi subjek penelitian. Besar sampel dalam penelitian ini adalah total sampling sebanyak 54 orang dengan perbandingan kasus dan kontro 1:1. Sampel yang memenuhi kriteria diberikan penjelasan mengenai penelitian, cara kerja, manfaat penelitian dan dimintai persutujan dan menandatangani formulir jika bersedia menjadi responden penelitian. Wawancara menggunakan pedoman kusioner dilakukan untukmemperoleh data karakteristik individu, riwayat kehamilan dan kunjungan antenatal care (ANC). Dilanjutkan dengan pengukuran kadar $\mathrm{CO}$ udara ekspirasi Ibu dengan menggunakan alat pengukur $\mathrm{CO}$ porTabel yaitu Micro ${ }^{+}{ }^{\text {TM }}$ Smokerlyzer.Analisis data dengan menggunakan program statistik komputer. Analisis deskriptif dilakukan berdasarkan jenis data numerik dan kategorikal. Analisis bivariate dilakukan dengan uji chi square dan uji stratifikasi menggunakan Mantel Handzel.

\section{Hasil}

Jumlah responden penelitian adalah sebanyak 27 kasus dan 27 kontrol. Pada Tabel 1 menunjukan distribusi frekuensi variabel kadar CO, umur, pekerjaan, pendidikan, status gizi, paritas, dan kunjungan antenatal care pada setiap kelompok kasus (BBLR) dan kontrol (BBLN). Hampir setengahnya dari jumlah responden memiliki nilai kadar $\mathrm{CO}$ pada kategori berbahaya (48.1\% pada kasus dan $40.7 \%$ pada kontrol). Lebih dari setengah ibu pada kelompok kasus memiliki umur yang beresiko saat hamil $(57,1 \%)$, adapun pada kelompok kontrol lebih dari setengahnya memiliki umur tidak beresiko saat hamil (52.5\%). Sekitar lebih dari setengahnya ibu pada kelompok kasus tidak memiliki pekerjaan (51\%), adapun pada kelompok kontrol lebih banyak ibu yang bekerja (55.6 \%). Berdasarkan variabel pendidikan, mayoritas latar belakang pendidikan ibu pada kelompok kasus merupakan lulusan sekolah menengah dan lebih tinggi (66.7\%), adapun pada kelompok kontrol lebih dari setengahnya berlatar belakang pendidikan sekolah menengah ke bawah (52.1). Mayoritas kelompok kasus $(63,6 \%)$ memiliki status gizi beresiko (LILA < 23.5) $\mathrm{cm}$, sedangkan kelompok kontrol lebih dari setengahnya $(53,5 \%)$ memiliki status gizi tidak beresiko (LILA $\geq 23.5 \mathrm{~cm})$. Selain itu, kelompok kasus mayoritas memiliki paritas $\geq 4$ anak $(83,3 \%)$ dan kunjungan antenatal yang tidak lengkap $<4$ kali sebanyak 66,7\%. Adapun kelompok kontrol lebih dari setengahnya memiliki paritas 1-3 anak (54,2\%) dan kunjungan antenatal yang lengkap $\geq 4$ kali $(52,1$

$\%)$.

$\underline{\text { Tabel 1. Distribusi Frekuensi Karakteristik Ibu di Kab. Kuningan }}$

\begin{tabular}{lcc}
\hline \multicolumn{1}{c}{ Variabel } & BBLR & BBLN \\
\cline { 2 - 3 } & n (\%) & n (\%) \\
\hline Kadar CO pada Ibu & $13(54.2)$ & $11(45.8)$ \\
Berbahaya & $14(46.7)$ & $16(53.3)$ \\
$\quad$ Normal & & \\
Umur (saat hamil) & $8(57.1)$ & $6(42.9)$ \\
$<20$ dan $>35$ (resiko) & $19(47.5)$ & $21(52.5)$ \\
$\quad 20-35$ (tidak beresiko) & & \\
Pekerjaan & $4(44.4)$ & $5(55.6)$ \\
Bekerja & $23(51.1)$ & $22(48.9)$ \\
$\quad$ Tidak Bekerja & $23(47.9)$ & $25(52.1)$ \\
Pendidikan & $4(66.7)$ & $2(33.3)$ \\
$\quad \leq$ Secondary School & & \\
$\quad$ High school & $5(83.3)$ & $1(16.7)$ \\
Paritas & $22(45.8)$ & $26(54.2)$ \\
$\quad \geq 4$ anak & & \\
1-3 anak &
\end{tabular}


Dari hasil uji chi-square dengan batas kemaknaan (alfa) sebesar $5 \%$, didapatkan bahwa tidak ada perbedaan proporsi kadar CO pada ibu pada kelompok kasus (BBLR) maupun kontrol (BBLN), Tabel 2.

Tabel 2. Hubungan Kadar CO pada Ibu dengan Kejadian Berat Badan Bayi Lahir di Kab. Kuningan

\begin{tabular}{lcccc}
\hline Variabel & BBLR & BBLN & \multirow{2}{*}{ OR $(95 \%$ CI $)$} & \multirow{2}{*}{ P-Value } \\
\cline { 2 - 3 } & $\mathrm{n}(\%)$ & $\mathrm{n}(\%)$ & & \\
\hline Kadar CO pada Ibu & & & & \multirow{2}{*}{0.584} \\
Normal & 51.9 & 59.3 & & 1.4 \\
Berbahaya & 48.1 & 40.7 & $(0.460-3.964)$ & \\
\hline
\end{tabular}

\section{Pembahasan}

Hasil penelitian menyatakan kadar CO ibu tidak berhubungan dengan kejadian berat badan bayi lahir rendah (BBLR). Meskipun uji hubungan menunjukkan tidak terdapat hubungan namun apabila dilihat dari tabel antara kadar CO pada ibu dengan kejadian BBLR maka akan diperoleh perbandingan jumlah responden yang mengalami BBLR diantara orang yang kadar CO ibu dalam kategori berbahaya dengan kadar $\mathrm{CO}$ ibu dalam kategori normal diperoleh hasil bahwa seseorang yang kadar $\mathrm{CO}$ dalam kategori berbahaya lebih banyak proporsinya yang mengalami BBLR (54,2\%) dibandingkan dengan ibu yang kadar $\mathrm{CO}$ nya dalam kategori normal (45,8\%). Tidak terdapatnya hubungan yang diperoleh dari hasil uji analisis dalam penelitian ini karena sedikitnya sampel yang diambil dalam penelitian ini. Jumlah sampel yang terlalu sedikit akan menyebabkan data yang dihasilkan terlalu homogen sehingga jika dilakukan analisis untuk uji hubungan akan didapatkan hasil tidak signifikan.

Menurut Stillman dalam Irnawati (2007), paparan karbon monoksida (CO) ibu hamil perokok pasif dapat menyebabkan kelahiran BBLR jika paparan tersebut terus menerus selama ibu hamil. Hal ini karena Karbon monoksida (CO) dapat diikat didalam haemoglobin ibu, sehingga mengakibatkan menurunnya kapasitas pengangkutan oksigen (O2) didalam darah ibu, sehingga tubuh janin akan menerima oksigen yang lebih sedikit. Ibu hamil sebagai perokok pasif dapat terpapar asap rokok dari berbagai tempat yang berbeda, hal ini disebut sebagai microenvironments. Microenvironments merupakan suatu tempat atau lokasi yang mungkin disinggahi setiap harinya oleh seseorang dalam kurun waktu yang lama. Adapun beberapa tempat yang termasuk dalam microenvironments adalah rumah, tempat kerja, tempat umum, dan transportasi umum.

Dalam penelitian ini ibu yang mengalami BBLR mayoritas adalah ibu yang tidak bekerja. Ibu menghabiskan sebagian banyak waktunya di rumah. Sebagian responden mengalami paparan asap rokok ketika suaminya berada dirumah (pulang bekerja dari luar kota). Penelitian ini sejalan dengan hasil penelitian Andrianasti (2017) yang menyatakan paparan asap rokok yang memiliki durasi sebentar (1 jam) bukan faktor risiko kejadian berat badan lahir rendah di Makassar. Berbeda dengan hasil peneitian Agnes (2016) yang menyatakan bahwa paparan asap rokok pada ibu (nilai $p$ : 0,003; OR:4,01; 95\%CI: 1,66-9,65) memiliki hubungan dengan kejadian BBLR di di Kecamatan Banyudono Kabupaten Boyolali.

Hasil penelitian ini perlu mempertimbangkan beberapa keterbatasan penelitian. Keterbatasan penelitian ini diantaranya adalah jumlah sampel yang sedikit dapat berdampak hasil yang didapatkan terlalu homogen. Selain itu, desain studi yang digunakan 
JURNAL ILMU KESEHATAN BHAKTI HUSADA: HEALTH SCIENCES JOURNAL, VOL. 10 NO. 01, JUNI 2019

DOI: https://doi.org/10.34305/jikbh.v10i1.86

yaitu case-control, hal ini berdampak pada tidak diketahuinya efek variabel luar oleh karena keterbatasan teknis yaitu variabel yang tidak ikut dikenakan waktu matching. Bias penelitian akibat tidak dilakukan pengukuran oleh peneliti, tetapi dalam penelitian ini peneliti melakukan pengukuran kadar $\mathrm{CO}$ langsung pada Ibu bayi/balita karena tidak ada data sebelumnya. Kelemahan pengukuran variabel secara restropektif tersebut adalah obyektivitas dan reliabilitasnya sehingga faktor-faktor risiko yang tidak jelas informasinya.

\section{Kesimpulan}

Hampir setengahnya dari jumlah responden memiliki nilai kadar $\mathrm{CO}$ pada kategori berbahaya (48.1 \% pada kasus dan $40.7 \%$ pada kontrol). Tidak ada perbedaan proporsi kadar CO pada ibu pada kelompok kasus (BBLR) maupun kontrol (BBLN). Hasil penelitian ini dapat menjadi acuan untuk penelitian selanjutnya dengan jumlah sampel yang lebi banyak dengan menambahkan beberapa variabel yang juga penting untuk dianalisis seperti frekuensi paparan asap diluar rumah.

\section{Daftar Pustaka}

De Bernabé, J. V., et al. 2004. Risk factors for low birth weight: a review. European Journal of Obstetrics \& Gynecology and Reproductive Biology, 116, 3-15.

Badriah, D.L. 2012. Metodologi Penelitian Ilmu-Ilmu Kesehatan. Bandung : Mutazam.

Badan Pusat Statisti. 2017. Data Kependudukan Kabupaten Kuningan. Kuningan: BPS

Dinas Kesehatan Kabupaten Kuningan. 2016. Profil Kesehatan kabupaten Kuningan. Kuningan: Dinas Kesehatan

Kementerian Kesehatan, RI. 2013. Laporan Hasil Riset Kesehatan Dasar (Riskesdas) 2013. Jakarta: Kementerian Kesehatan RI.

Kementerian Kesehatan, RI. 2007. Laporan Hasil Riset Kesehatan Dasar (Riskesdas) 2007. Jakarta: Kementerian Kesehatan RI.
Kementerian Kesehatan, RI. 2010. Laporan Hasil Riset Kesehatan Dasar (Riskesdas) 2010. Jakarta: Kementerian Kesehatan RI.

Leonardi-Bee, J., et al. 2008. Environmental tobacco smoke and fetal health: systematic review and meta-analysis. Archives of Disease in Childhood-Fetal and Neonatal Edition, 93, F351-F361.

Lestari, K. S. D. \& Mangku, K. 2015. Paparan Asap Rokok pada Ibu Hamil di Rumah Tangga terhadap Risiko Peningkatan Kejadian Bayi Berat Lahir Rendah di Kabupaten Gianyar. Public Health And Preventive Medicine Archive, 3.

Mahayana, S. A. S. \& Chundrayetti, E. 2015. Faktor Risiko yang Berpengaruh terhadap Kejadian Berat Badan Lahir Rendah di RSUP Dr. M. Djamil Padang. Jurnal Kesehatan Andalas, 4.

Marlenywati, M., Hariyadi, D. \& Ichtiyati, F. 2017. Faktor-Faktor Yang Mempengaruhi Kejadian BBLR RSUD Dr Soedarso Pontianak. Jurnal Vokasi Kesehatan, 1.

Martin, T. R. \& Bracken, M. B. 1986. Association of low birth weight with passive smoke exposure in pregnancy. American Journal of Epidemiology, 124, 633-642.

Murray, C. J. L.,., et al. Global, regional, and national disability-adjusted life years (DALYs) for 306 diseases and injuries and healthy life expectancy (HALE) for 188 countries, 1990\&\#x2013;2013: quantifying the epidemiological transition. The Lancet, 386, 2145-2191.

Menteri Kesehatan RI. 2013. Peraturan Menteri Kesehatan RI Nomor 28 Tahun 2013 tentang Pencantuman Peringatan Kesehatan dan Informasi Kesehatan Pada Kemasan Produk Tembakau. Jakarta: Kemenkes RI

Narita, A., Yuli Kusumawati, S., Kes, M. \& Wijayanti, A. C. 2016. Faktor Risiko Usia, Pekerjaan Dan Paparan Asap Rokok Pada Ibu Dengan Kejadian Berat Bayi Lahir Rendah Di Kecamatan Banyudono Kabupaten Boyolali. Universitas Muhammadiyah Surakarta.

Notoadmodjo S. 2010. Metodologi Penelitian Kesehatan. Jakarta: Rineka Cipta 
JURNAL ILMU KESEHATAN BHAKTI HUSADA: HEALTH SCIENCES

JOURNAL, VOL. 10 NO. 01, JUNI 2019

DOI: https://doi.org/10.34305/jikbh.v10i1.86

Prawirohardjo S. 2014. Pelayanan kesehatan maternal dan neonatal. Jakarta: PT bina pustaka sarwono prawirohardjo

Proverawati, A. 2010. BBLR: Berat Badan Lahir Rendah. Yogyakarta: Nuha Medika

Pieraccini, G., et al. 2008. Identification And Determination Of Mainstream And Side Stream Smoke Components In Different Brands And Types Of Cigarettes By Means Of Solid-Phase Microextraction-Gas ChromatographyMass Spectometry. Journal of Chromatography. 1180(1): 138-150

Ramadhan, N. 2012. Hubungan ibu hamil perokok pasif dengan kejadian bayi berat lahir rendah di badan layanan umum daerah RSU Meuraxa Banda Aceh. Jurnal Ilmiah STIKES U'Budiyah Vol, 1.

Ritz, B. \& Yu, F. 1999. The effect of ambient carbon monoxide on low birth weight among children born in southern California between 1989 and 1993. Environmental Health Perspectives, 107, 17-25.

Salmasi, G., Grady, R., Jones, J., Mcdonald, S. D. \& Group*, O. B. O. T. K. S. 2010. Environmental tobacco smoke exposure and perinatal outcomes: a systematic review and meta-analyses. Acta obstetricia et gynecologica Scandinavica, 89, 423-441.

Smokerlyzer. 2015. Diakse dari www.bedfont.com.

Wardlaw, T. M. 2004. Low birthweight: country, regional and global estimates, UNICEF.

Zulardi AR. 2014. Hubungan Lingkungan Perokok Dengan Ibu Hamil Terpapar Asap Rokok Terhadap Kejadian Bayi Berat Lahir Rendah di Surakarta.[Skripsi]. Surakarta: Universitas Sebelas Maret

Dinas Kesehatan Kabupaten Kuningan. 2016. Profil Kesehatan kabupaten Kuningan. Kuningan: Dinas Kesehatan

Sistiarani C. Faktor Maternal dan Kualitas Pelayanan Antenatal yang Berisiko terhadap Kejadian Berat Badan Lahir Rendah (BBLR). Universitas Diponegoro. 2008.

Agtini, M. D., Budiarso, R. L., Lubis, A., Bakri, Z., \& Kristanti, C. M. (1996). Dampak Pemberian Tablet Zat Besi (Fe) pada
Ciptaan disebarluaskan di bawah

Lisensi Creative Commons Atribusi-

NonKomersial-BerbagiSerupa 4.0

Internasional.

Ibu Hamil terhadap Kejadian Bayi dengan Berat Badan Lahir Rendah (Analisis Lanjut SDKI 1994). Buletin Penelitian Kesehatan, 24(2\&3 Sept).

Demelash, H., Motbainor, A., Nigatu, D., Gashaw, K., \& Melese, A. (2015). Risk factors for low birth weight in Bale zone hospitals, South-East Ethiopia: a case-control study. BMC pregnancy and childbirth, 15(1), 264. 